28. Zalunina, O. M. Construction of aggregates of features of the building complex of the territory for conceptual grouping scheme [Text] / O. M. Zalunina // Eastern-European Journal of Enterprise Technologies. - 2014. - Vol. 4, No. 3 (70). P. 29-33. doi:10.15587/1729-4061.2014.26278

29. Zalunina, O. M. Postroenie kontseptual'noy skhemy gruppirovki oblastey Ukrainy po makroekonomicheskim parametram v stroitel'nom sektore [Text] / O. M. Zalunina // Problemy ekonomiki. - 2014. - Vol. 4. - P. 91-96.

30. Zalunina, O. M. Determine the relationship of industries related to regional development [Text] / O. M. Zalunina // Technology Audit and Production Reserves. - 2015. - Vol. 1, No. 7 (21). - P. 8-12. doi:10.15587/2312-8372.2015.38434

31. Zalunina, O. M. The economic dimension of management decisions in the building industry [Text] / O. M. Zalunina // ScienceRise. 2015. - Vol. 9, No. 1 (14). - P. 42-46. doi:10.15587/23138416.2015.50512

32. Zalunina, O. M. Formation of optimal production scale of building materials [Text] / O. M. Zalunina // Technology Audit and Production Reserves. - 2016. - Vol. 1, No. 3 (27). P. 45-49. doi:10.15587/2312-8372.2016.60447

33. Zalunina, O. M. Construction of complex index for evaluation of investment attractiveness of building projects [Text] / O. M. Zalunina // ScienceRise. - 2016. - Vol. 5, No. 1 (22). P. 41-45. doi:10.15587/2313-8416.2016.69662

34. Zalunina, O. M. Formation of condition severity index of the industrial-building systems [Text] / O. M. Zalunina // Technology Audit and Production Reserves. - 2016. - Vol. 2, No. 5 (28). - P. 38-42. doi:10.15587/2312-8372.2016.65971
35. Zalunina, O. M. Formuvannia bahatorivnevoi systemy pokaznykiv vymiru dobrobutu naselennia [Text] / O. M. Zalunina, V. V. Druzhynina, N. F. Aleksieieva // Aktualni problemy ekonomiky. - 2017. - Vol. 4 (190). - P. 100-112.

36. Zalunina, O. M. Prioritety informatsionnogo polya, ispol'zuemye v upravlenii predpriyatiem [Text] / O. M. Zalunina // Naukoviy visnik Uzhgorods'kogo natsional'nogo universitetu. Seriya «Mizhnarodni ekonomichni vidnosini ta svitove gospodarstvo». - 2016. - Vol. 6. - P. 132-135.

\section{ФОРМИРОВАНИЕ БЛОКОВ КАТЕГОРИАЛЬНОГО АПЛАРАТА СТРОИТЕЛЬНОЙ ОТРАСЛИ}

Проанализирован зарубежный опыт по вопросам развития строительной отрасли. Классифицированы существующие подходы к понятию строительная отрасль. Предложено рассматривать строительную отрасль как детенсивную экономическую систему в строительстве, объединяющую деятельность совокупности предприятий и производств, обладающих признаком ресурсного единства. Сформированы блоки категориального аппарата, включающие промышленный, отраслевой, управленческий и социальный подходы.

Ключевые слова: строительная отрасль, строительный комплекс, строительные организации, строительство, блоки.

Zalunina Olga, PhD, Associate Professor, Department of Management, Kremenchuk Mykhailo Ostrohradskyi National University, Ukraine, e-mail: olvialavina@gmail.com, ORCID: http://orcid.org/ 0000-0002-7478-4528

\title{
Lisun $\mathbf{Y}$.
}

\section{INVESTIGATION OF RELATIONSHIP MARKETING IN THE FRANCHISING ACTIVITY OF TRADE COMPANIES}

В роботі автором уточнено сутність та складові понять «маркетинг відносин», «маркетинг взаємодї», «партнерство» в торговельному підприємництві. Досліджено сутність терміну «дистрибуиія» та «франчайзинг» та визначено місие франчайзингу у структурі організачійно-правових форм дистрибуиійних систем. Узагальнено сильні та слабкі сторони франчайзингової діяльності з використанням SWOT-аналізу.

Ключові слова: підприємництво, торгівля, дистрибуція, партнери, франчайзинг, маркетинг взаємодї̈, узгодження інтересів, ефективність, сталий розвиток.

\section{Introduction}

In dynamic competitive conditions, the marketing aspect of mutual relations and interaction of companies becomes especially important, since it is marketing that integrates the goods and services of the company, their perception by consumers, location and promotion, taking into account the actions of competitors and business partners. The theoretical and methodological aspects of marketing relationship of trade companies operating on the basis of franchising require further study.

\section{The object of research and its technological audit}

The author researches the marketing aspect of mutual relations and interaction of companies, since it is marketing that integrates the goods and services of the company, their perception by consumers, place and promotion, taking into account the actions of competitors and business partners. Further theoretical and methodological aspects of relationship marketing of trading companies operating on the basis of franchising have been obtained. Scientific research is aimed at clarifying the essence and components of relationship marketing in the field of trade and determining its features, due to the technology of franchising.

\section{The aim and objectives of research}

The aim of the article is investigation of the theoretical and methodical aspects of relationship marketing in supply chains in the implementation of commercial entrepreneurship on the basis of franchising. Achieving the aim of research necessitated the solution of the following tasks: 
1. To conduct a comparative analysis of the essence of the concepts of «relationships», «interaction», «relationship marketing», «marketing interaction», «partnership» in commercial entrepreneurship.

2. To explore the essence of the term «distribution» and «franchising» and define franchising in the structure of organizational and legal forms of distribution systems.

3. To monitor the activities of trade companies and the franchising market in Ukraine.

4. To summarize the strengths and weaknesses of franchising with the use of SWOT analysis, in order to clarify the nature of partnerships in trading companies operating on the basis of franchising.

5. To carry out the segmentation of franchises in the sphere of trade on such criteria as investment, the cost of the franchise, the payback period, the number of personnel, technological requirements for doing business, in order to clarify the priority of the manifestation of partnership relations.

\section{Research of existing solutions of the problem}

The competitive environment raises requirements to the quality of products and customer service, requires a purposeful and systematic formation of loyal consumer demand. In this connection, the issues of mutually beneficial cooperation, strategic partnership, construction of activities based on relationship marketing acquire the topicality [1,2].

The questions of relationship marketing are investigated by domestic scientists and scientists from the near abroad [3-8]. Marketing, logistics, commercial, technological aspects of distribution and the activities of trade companies are investigated in [9-17].

The works $[18,19]$ are devoted to investigations of the relationship marketing and interaction in supply chains, as an important component of trading activity. The problems of distribution, inter-channel and intra-channel cooperation are covered in the work [20]. The work [21] is devoted to the issues of relationship marketing in supply chains.

Relationship marketing ensures the construction and regulation of processes in the management system in order to ensure the maximum satisfaction of the interests of all partners at the expense of personal, individualized continuous contacts [6, 7]. In this aspect, franchising as one of the effective forms of business relations in entrepreneurship, enhances the achievements and advantages of relationship marketing, acting as a platform for its implementation.

Theoretical aspects of franchising, the construction of network franchise structures, the formation of franchising relationships and their regulatory support are studied in the works of domestic and foreign scientists [22-27].

In providing competitive advantages in a series of trades, it is not only the advantageous price of an integrated trading offer that is of decisive importance, but also the increase in the value of the trade offer for consumers. Therefore, further research requires aspects of both the relationship marketing in supply chains and the overall marketing of interaction in the franchising activities of trade companies.

\section{Methods of research}

The methodological basis of the research is a set of scientific methods of dialectical and comparative analysis, synthesis, grouping and generalization. The basis of quantitative re- search results is the official information of the State Statistics Service of Ukraine and the data of the Franchise Group.

The methodological essence of the research results is that relationship marketing in supply chains is considered as an identification tool and increasing the value of the potential aggregate proposition of supply chains for the segment and the specific consumer, the mechanism for effective implementation of such proposition, and ensuring the value of strategic relationships. Integration of relationship marketing and supply chain management of trade companies is interpreted in the concept of demand chain management, based on a purposeful systematic formation and increase in value for the end user. This approach contributes to addressing the issues of increasing the price of an integrated supply and its value to consumers.

\section{Research results}

The analysis of literary sources testifies to the lack of an unambiguous approach to the interpretation of the essence and content of the concepts of «mutual relations» and «relationship».

A number of scientists (V. Cherenkov) treats the term «relations» from the standpoint of the resource approach, as reserve opportunities or resources in the idle state $[6,28]$, emphasizing the difference in the term «interaction» that consists in the action of the elements on each other, the result of which is the creation new quality elements.

Other scientists hold diametrically opposite opinions, noting that the essence of the term «relation» («relation marketing») is not contradicting the term «relationship» («relationship marketing») and treat them as synonyms. That is, relationships are considered as «a category reflecting certain systemic processes of the action of elements on each other, their mutual conditioning and generation by one subject to another. Relationships in any system are an objective and universal form of its movement and development through the appropriate links between the relevant elements. They determine the existence and organization of any system» [6].

In our opinion, processes realized through appropriate links that do not involve a change in the quality of the object (properties of elements) are treated as «relationships». And the processes that cause a change in the quality of the object (the properties of the elements) cause the feedback of the object in the form of a change in its properties are treated as «interaction». That is, interaction is a «concentrated form» of active relationships [29-31].

Relationship marketing, in contrast to classical marketing, provides for the continuation of the process after the commission of an act of sale (exchange) in order to meet the needs (parties' goals) and the formation of long-term relationships with consumers and partners (stakeholders) involved in communications [30]. This is the place of marketing in the formation of partnership interaction (interdependent actions) of companies.

Relationship marketing is most revealing in the distribution, promotion and marketing of products. I. Mischuk and V. Lozinsky note that distribution «is a complex system in which a producer of products and various intermediaries are involved, which on a contractual basis jointly ensure the implementation of a set of activities for the promotion of products to the final consumer and sale» [15].

Distribution is the process of promoting goods to the final consumer with the involvement of distributors and 
dealers, applying a single marketing and technology policy, approved by the supplier (manufacturer) [9].

The main organizational and legal forms of distribution systems are: a business company, a franchise network, a partner network, a purchasing group.

Investigating the sphere of franchising and relationship marketing, partnership is of key importance, which is expedient to understand as a kind of relations between different actors, the meaning of which is forming a unified position on certain issues and organize joint actions. When implementing a partnership in the sphere of trade, in the process of interaction between the buyer and the seller, the main components are the contract, obligations, agreement, the right to conduct a pre-defined type of economic activity [30]. It is these concepts and categories that constitute the essence of franchising, as one of the organizational and legal forms of the distribution of their systems.

Franchising is advisable to understand «entrepreneurial activity on which, on a contractual basis, one party (the franchisor) undertakes to transfer to the other party (franchisee) for a remuneration for a certain period a set of exclusive rights to use the sign for goods and services, brand name, services, technological process and (or) of specialized equipment, know-how, commercial information protected by law, as well as other objects of exclusive rights (franchise) stipulated by the agreement» [27].

The activities of trade companies, in particular the distribution system in the sphere of commodity exchange, function through the realization of such processes (supply chains) as: the order of goods, formation of stock of goods, storage and transportation, redistribution, packaging and transport technology. The main goal of supply chain management for franchising trading companies is to «... achieve the interests of participants in such chain by ensuring the economic efficiency of the material flow» [6].

This approach contributes to solving the issues of increasing the price of an integrated supply and its value for consumers, which is the essence of trading activity, the indices of changes in the main indicators of which are presented in Fig. 1.

The main structural indicators of trade companies are: the number of companies, volume of sales, number of employed workers.

When constructing a mechanism for marketing relationship of trade companies, it is necessary to take into account the following features (Table 2, Fig. 2):

- small companies (in particular very mills) account for the overwhelming majority - $97 \%$, accumulating $40 \%$ of employed workers and forming $23.7 \%$ of the volume of sold products;

- medium-sized companies account for $2.9 \%$ of total employment, providing employment for $33.4 \%$ of employees and forming $46.1 \%$ of sales;

- large companies account for $0.1 \%$, accumulating almost a quarter (26.6\%) of employed workers and forming a third $(30.2 \%)$ of the volume of sales.

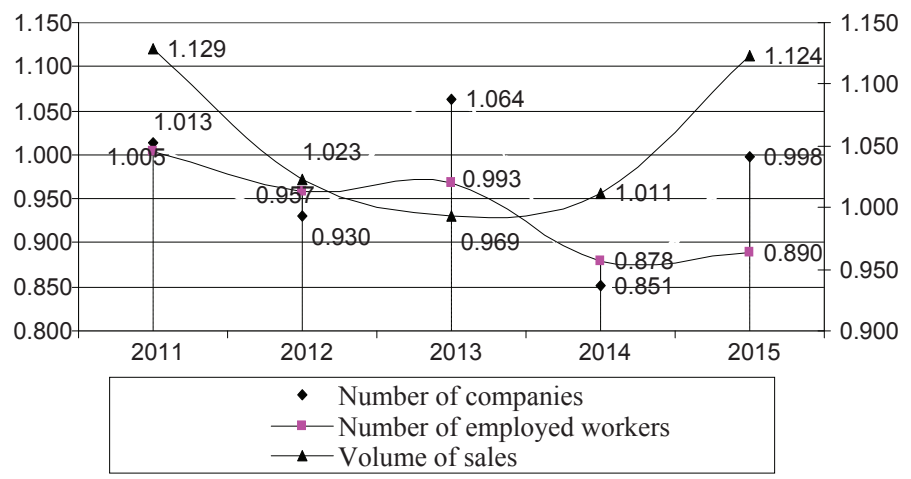

Fig. 1. Indices of the basic structural indicators of wholesale and retail trade companies (built by the author) [32]

The main structural indicators of companies by their size by type of economic activity «Wholesale and retail trade; repair of motor vehicles and motorcycles» [32]

\begin{tabular}{|c|c|c|c|c|c|c|}
\hline & 2010 & 2011 & 2012 & 2013 & 2014 & 2015 \\
\hline Number of companies, total & 110154 & 111638 & 103798 & 110414 & 93972 & 93798 \\
\hline large companies, \% & 0.2 & 0.2 & 0.2 & 0.2 & 0.1 & 0.1 \\
\hline medium-sized companies, \% & 3.7 & 3.7 & 3.8 & 3.3 & 3.2 & 2.9 \\
\hline small companies, \% & 96.1 & 96.1 & 96.0 & 96.5 & 96.7 & 97.0 \\
\hline of them are very small, \% & 82.7 & 82.9 & 82.4 & 84.4 & 85.2 & 86.1 \\
\hline Volume of sold products, total & 1406132.7 & 1587116.5 & 1623609.6 & 1612134.4 & 1629690.6 & 1831054.7 \\
\hline large companies, \% & 29.3 & 30.7 & 29.6 & 30.7 & 32.2 & 30.2 \\
\hline medium-sized companies, \% & 45.6 & 46.7 & 48.3 & 47.7 & 45.1 & 46.1 \\
\hline small companies, \% & 25.1 & 22.6 & 22.1 & 21.6 & 22.7 & 23.7 \\
\hline of them are very small, \% & 8.0 & 7.2 & 7.2 & 7.1 & 7.7 & 8.1 \\
\hline Number of employed workers, thous. & 1241.1 & 1246.7 & 1193.4 & 1156.0 & 1015.2 & 903.4 \\
\hline large companies, \% & 21.1 & 22.1 & 25.2 & 27.4 & 27.7 & 26.6 \\
\hline medium-sized companies, \% & 34.6 & 34.1 & 32.6 & 31.7 & 33.6 & 33.4 \\
\hline small companies, $\%$ & 44.3 & 43.8 & 42.2 & 40.9 & 38.7 & 40.0 \\
\hline of them аге very small, \% & 19.6 & 19.8 & 19.2 & 19.1 & 19.2 & 20.7 \\
\hline
\end{tabular}


The main structural indicators of companies by their size by type of economic activity «Wholesale and retail trade; repair of motor vehicles and motorcycles» [32]

\begin{tabular}{|l|c|c|c|c|c|}
\hline & 2010 & 2011 & 2012 & 2013 & 2015 \\
\hline Number of companies, total & 110154 & 111638 & 103798 & 110414 & 93972 \\
\hline Financial result (balance), million UAH & 14883.5 & 21591.5 & 9608.0 & -6047.5 & -128134.8 \\
\hline Share of profitable companies, \% & 62.5 & 66.7 & 66.0 & 67.2 & -86341.7 \\
\hline Share of loss-making companies, \% & 37.5 & 33.3 & 34.0 & 32.8 & 76.0 \\
\hline The level of profitability (loss) & 9.8 & 15.0 & 12.2 & 10.2 & 33.3 \\
\hline
\end{tabular}

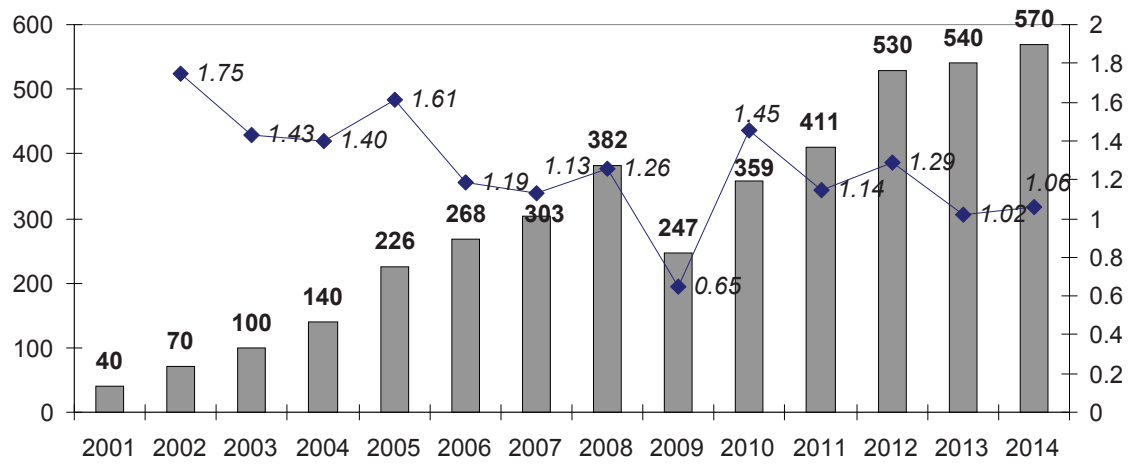

$\square$ The number of franchisors

- Rate of change to the previous year

Fig. 2. Dynamics of the number of franchisors for 2001-2014 [33, 34]

The development of partnership and relationship in the business environment is based on the use of various resources: material, technical, energy, personnel, information and unconditionally financial (Table 2).

The worsening of the general economic situation adversely affected the financial condition of the trade companies and led to the loss of wholesale and retail trade in the macroeconomic aspect: the financial result of 2015 amounted to 86341.7 million UAH and the level of profitability (loss) - $2.4 \%$ [32].

At the same time, a positive phenomenon is the decrease in the share of loss-making companies for 2014-2015 from $33.3 \%$ to $24 \%$. The level of losses of companies by $2015-2.4 \%$ compared to the same indicator for the previous period $-12.8 \%$ [32].

According to the Franchise Group, franchise objects predominate in business ownership in Ukraine: public catering $-75 \%$; retail $-77 \%$; services to the population $79 \%$ [33, 34]. During the 2008-2014, the number of franchisors increased from 240 to 567 units; the number of franchising objects increased from 14.700 to 31.750 units; the number of international franchises and brands increased from 38 to 187 [33].

In total, franchisors who work in Ukraine, 425 companies are actively expanding their networks by opening their own and franchising facilities (Fig. 2).

According to the Franchise Group in the structure of franchising in Ukraine, the most developed is public catering, trade in light industry goods, car service and household services. In terms of price policy, franchises of household services are more accessible, and objects of hotel and restaurant business and production make up the segment of expensive franchises.

\section{SWOT analysis of research results}

Using the SWOT analysis method, it is expedient to analyze the strengths and weaknesses, opportunities and threats of franchising of trading companies (Table 3, 4).

The processes of distribution, promotion and marketing of products at the levels of all participants of the franchise network are characterized by a number of differences in the control and coherence of policy in marketing, financial, organizational and managerial aspects (Table 4).

The franchise distribution system for light industry goods (clothing and footwear) is characterized by a low degree of partnership in the relations of the concerned parties, since the franchisor determines the conditions and principles of cooperation and franchisees cause little influence on the development of the network. Franchising in the sphere of clothing trade is more uniform in terms of the amount of investments (especially the segment «youth clothing»), personnel and technological requirements of doing business (Table 5).

So, in terms of the number of brands in the Ukrainian market, franchises predominate in the direction «Women's Clothing», «Women's and Men's Clothing». In second place by the number of brands are franchises in the direction of «Men's Clothing» and «Sportswear». The separate segments of the market is franchising for the sale of children's clothing and footwear. 
Opportunities and threats of franchising of trading companies [34, 35]

\begin{tabular}{|c|c|}
\hline Opportunities $_{\text {ppos }}$ & Threats \\
\hline $\begin{array}{l}\text { 1. Development of small and medium- } \\
\text { sized business. } \\
\text { 2. Development of logistics and distribu- } \\
\text { tion channels. } \\
\text { 3. Development of a franchise network. } \\
\text { 4. Development of marketing and adver- } \\
\text { tising technologies. } \\
\text { 5. Offers in the labor market for the } \\
\text { selection of personnel. } \\
\text { 6. Improvement of production and ser- } \\
\text { vice technologies. } \\
\text { 7. Expansion of cooperation with busi- } \\
\text { ness partners in a single technological } \\
\text { space. } \\
\text { 8. Formation of long-term relations with } \\
\text { stakeholders on the basis of relationship } \\
\text { marketing }\end{array}$ & $\begin{array}{l}\text { 1. Increase in the cost of resources. } \\
\text { 2. Decline in the purchasing power } \\
\text { of consumers. } \\
\text { 3. Change in the behavioral cha- } \\
\text { racteristics of the end user, fluctua- } \\
\text { tions in demand. } \\
\text { 4. Activation of competitors. } \\
\text { 5. Improving the quality standards } \\
\text { of goods and services. } \\
6 \text {. Complications of legal support } \\
\text { for the franchise network: little } \\
\text { clear procedure for selection and } \\
\text { selection criteria for network par- } \\
\text { ticipants; Complications and ap- } \\
\text { proval of the terms of contractual } \\
\text { relations }\end{array}$ \\
\hline
\end{tabular}

Table 4

Strengths and weaknesses of franchising of trading companies [34, 35]

\begin{tabular}{|c|c|}
\hline Strengths & Weaknesses \\
\hline \multicolumn{2}{|c|}{ For a franchisor (franchise provider) } \\
\hline $\begin{array}{l}\text { Marketing and financial aspect: } \\
\text { 1. Stabilization of turnover and profit } \\
\text { from activities through the provision } \\
\text { of a franchise. } \\
\text { 2. Rapid promotion and development } \\
\text { of the network brand. } \\
\text { 3. Rational costs for expanding distri- } \\
\text { bution channels. } \\
\text { 4. Optimization and reduction of costs } \\
\text { for promotions and advertising. } \\
\text { Organizational and management as- } \\
\text { pect: } \\
\text { 5. Monitoring of business activities of } \\
\text { participants in a franchise network. } \\
\text { 6. Distribution of competences and } \\
\text { responsibilities on a third party (custo- } \\
\text { mers, supervisory bodies). } \\
\text { 7. Orderliness of recruitment and ma- } \\
\text { nagement of personnel }\end{array}$ & $\begin{array}{l}\text { Marketing and financial aspect: } \\
\text { 1. Obtaining a smaller part of the } \\
\text { profit (the main part of the income } \\
\text { of the franchisee). } \\
\text { 2. Difficulties with the introduction } \\
\text { of a franchise in an unsaturated } \\
\text { competitive market. } \\
\text { Organizational and management as- } \\
\text { pect: } \\
\text { 3. Insufficient motivation of the fran- } \\
\text { chisee (in matters of business pro- } \\
\text { fitability). } \\
\text { 4. The need for legal support for } \\
\text { the brand. } \\
\text { 5. The possibility of separating the } \\
\text { franchisee, in case of strengthening } \\
\text { the position in the market. } \\
\text { 6. The probability of non-transparent } \\
\text { reporting by the franchisee (under- } \\
\text { stating the level of profit and cor- } \\
\text { responding payments to the fran- } \\
\text { chisor). } \\
\text { 7. Failure to comply with franchisee } \\
\text { requirements and standards of the } \\
\text { agreement }\end{array}$ \\
\hline \multicolumn{2}{|c|}{ For franchisee (recipient of franchise) } \\
\hline $\begin{array}{l}\text { Marketing and financial aspect: } \\
\text { 1. Risk reduction in starting a business. } \\
\text { 2. Receiving assistance in financing. } \\
\text { 3. Obtaining economic, social, environ- } \\
\text { mental benefits through economies of } \\
\text { scale (network effect). } \\
\text { 4. Use the achievements and advanta- } \\
\text { ges of marketing research, advertising } \\
\text { campaigns, promotions in the network } \\
\text { at the expense of the franchisor. } \\
\text { Organizational and management aspect: } \\
\text { 5. Favorable terms of cooperation with } \\
\text { counterparties and network participants. } \\
\text { 6. Rules for the functioning and de- } \\
\text { velopment of the network, corporate } \\
\text { culture. } \\
\text { 7. The possibility of learning by using } \\
\text { experience, trademark, copyright or } \\
\text { trademark. } \\
\text { 8. Obtaining assistance in choosing the } \\
\text { location of the franchise facility }\end{array}$ & $\begin{array}{l}\text { Marketing and financial aspect: } \\
\text { 1. Restriction of sale (territory, the } \\
\text { structure of goods, suppliers are } \\
\text { regulated). } \\
\text { 2. Inefficient policy of the franchisor } \\
\text { can have a negative impact on the } \\
\text { profitability of the franchisee. } \\
\text { 3. Financial expenses (license pay- } \\
\text { ments, contributions to the adver- } \\
\text { tising budget of the network). } \\
4 \text {. High costs of adaptation to es- } \\
\text { tablished standards in the field of } \\
\text { merchandising. } \\
\text { Organizational and management as- } \\
\text { pect: } \\
5 \text {. Control by the franchisor. } \\
6 \text {. Insufficient motivation from the } \\
\text { franchisor. } \\
7 \text {. Losses associated with leaving } \\
\text { the network }\end{array}$ \\
\hline
\end{tabular}

The segmentation of the franchise market in Ukraine in the sphere of trade (clothing and footwear) $[33,34]$

\begin{tabular}{|c|c|c|c|c|}
\hline $\begin{array}{c}\text { Trade name, market } \\
\text { segment }\end{array}$ & $\begin{array}{l}\text { Investments, } \\
\text { thousand UAH }\end{array}$ & $\begin{array}{l}\text { Payback pe- } \\
\text { riod, months }\end{array}$ & \begin{tabular}{|c|} 
Staff, \\
people
\end{tabular} & $\begin{array}{l}\text { Areas, } \\
\mathrm{m}^{2}\end{array}$ \\
\hline \multicolumn{5}{|c|}{ Women's clothing } \\
\hline $\begin{array}{l}\text { TM Karen Millen } \\
\text { (England) }\end{array}$ & $800-1200$ & $12-18$ & 4 & 80 \\
\hline KRISSTEL TM & $800-900$ & - & $2-3$ & $50-100$ \\
\hline TM MAXA (Italy) & 590-260 & $18-24$ & $2-3$ & $50-100$ \\
\hline $\begin{array}{c}\text { TM «Meliø» } \\
\text { («smart casual») }\end{array}$ & 367 & $6-18$ & 2 & $40-70$ \\
\hline TM «Cat Orange» & $150-350$ & $6-12$ & - & $50-100$ \\
\hline TM «JHIVA» & 95-100 & $6-8$ & 3 & 60 \\
\hline \multicolumn{5}{|c|}{ Men's clothing } \\
\hline $\begin{array}{l}\text { TM «Vaismann» } \\
\text { (Germany) }\end{array}$ & $880-1100$ & $18-24$ & $4-5$ & 80-130 \\
\hline $\begin{array}{l}\mathrm{TM} \text { «VDane» } \\
\text { («Vidivan») }\end{array}$ & $550-1250$ & $6-16$ & - & 80-200 \\
\hline \multicolumn{5}{|c|}{ Men's and women's clothing } \\
\hline $\begin{array}{l}\text { TM Tom Tailor } \\
\text { (Germany) }\end{array}$ & $1600-2000$ & $24-36$ & 5 & $120-350$ \\
\hline TM «Top Secret» & 500 & $18-24$ & - & - \\
\hline TM «GARSIA» & $120-1000$ & $36-48$ & 3 & 70 \\
\hline TM Sella & 600 & 24 & - & - \\
\hline \multicolumn{5}{|c|}{ Youth clothing } \\
\hline TM OASIS & $800-1200$ & $12-18$ & 4 & 80 \\
\hline $\begin{array}{l}\text { TM «Pimkie» } \\
\text { (France) }\end{array}$ & 800-1200 & $24-36$ & 4 & 80 \\
\hline $\begin{array}{c}\text { TM «Bip Curl» } \\
\text { (Australia) }\end{array}$ & 800-1200 & $12-18$ & 4 & 80 \\
\hline \multicolumn{5}{|c|}{ Sportswear } \\
\hline $\begin{array}{c}\text { TM «BONA Sport» } \\
\text { (Ukraine) }\end{array}$ & $1000-1200$ & $16-18$ & 3 & $100-120$ \\
\hline TM Columbia (USA) & $324-600$ & $12-24$ & 10 & 100 \\
\hline TM KELME (5pain) & $120-800$ & $12-18$ & 4 & 80 \\
\hline $\begin{array}{l}\text { TM «Trespass» } \\
\text { (England) }\end{array}$ & $120-800$ & $12-18$ & 4 & 80 \\
\hline \multicolumn{5}{|c|}{ Children's clothing } \\
\hline TM «Parasola» & $230-250$ & $12-18$ & 4 & 40 \\
\hline TM BabyArt & 15 & $3-6$ & 1 & $15-50$ \\
\hline \multicolumn{5}{|c|}{ Footwear } \\
\hline TM «Milana» (Italy) & 2000 & 18 & 4 & $100-130$ \\
\hline TM Antonio Biaggi & $1000-1500$ & $16-18$ & 5 & $100-150$ \\
\hline TM «Respect» & 700 & $10-15$ & 4 & $80-25$ \\
\hline Cracs TM & $300-500$ & $12-18$ & 5 & $40-80$ \\
\hline TM «Ti Amo» & 300 & 12 & 4 & 70 \\
\hline
\end{tabular}

Capital investments in the sphere of franchising (Table 5) can be conditionally divided on the level: high (8001200 thousand UAH), medium (260-600 thousand UAH), low (95-150 thousand UAH). The payback period of franchising projects with a high level of investment is on average 18-24 months. The required number of staff averages from 3 to 10 people. 


\section{Conclusions}

By results of researches, it is necessary to note:

1. The use of the term «relationship» is broader than the term «mutual relations», as it provides for mutual action and changes in the characteristics of participants in franchising: franchisor, franchisee, consumers and other business entities. Relationship marketing is a mechanism for the development of business entities based on the integration of basic functions, partnerships of mutually beneficial managerial and corporate interests.

2. A franchise network is one of the organizational and legal forms of distribution systems that can also be represented by an economic company, a partner network, a purchasing group. The franchise network is characterized by an average level of interaction, since the actions of the main participants are regulated in accordance with the terms of the franchise.

Within the framework of franchising, there are various forms and principles of cooperation, ranging from the simplest ones, which are the distribution of franchisor's goods using its brand and trade standards, to the most complex form of cooperation, which consists in offering an entire franchise system.

3. Monitoring of the activities of Ukrainian trade companies at the end of 2015 evidences about a reduction in the number of trade companies, and the number of employed workers. At the same time, an overwhelming number $(97 \%)$ are small companies that provide $40 \%$ of employed workers and $23.7 \%$ of the volume of sold products.

4. Strategic analysis of franchising activities using SWOT analysis shows that the main threats to franchising in Ukraine are: increasing the cost of resources, activating competitors, changing behavioral characteristics of consumers and complicating the legal field of franchising. Weaknesses are: difficulties with using a franchise in an unsaturated competitive market; insufficient motivation of the franchisee; high costs of adaptation to established standards in the field of merchandising and advertising.

According to the results of the SWOT analysis, it is established that franchising in the sphere of trade requires: improving the legal support for franchising; implementation of a flexible tax policy; assistance at the level of government programs and programs of the Franchising Association for the Development of Small and Medium-sized Businesses; implementation of regional support for small and medium-sized businesses, which is concentrated most of the employed workers and the volume of sold products.

5 . The segmentation of participants in the franchise network makes it possible to establish that in the sphere of trade in light industry goods, franchising is realized in the following directions: «women's clothing», «man's clothes», «men's and women's clothing», «youth clothing», «sportswear», «children's clothing» clothes, shoes».

The change in the behavioral characteristics of groups of consumers (women, youth, people involved in sports) has a particular importance. When forming and promoting the interaction of franchising activities of trade companies, it is advisable to take into account the following signs of network participants: parameters of competitive behavior, distribution channels, supply chain planning, institutional relations and specialization, long-term functioning and development [36-39]. Relationship marketing facilitates the adoption of consolidated decisions on the competitive behavior of the manufacturer, the seller and the consumer, the institutionalization of relations, the achievement of common interests of all stakeholders.

In the sphere of trade, there is a need to compose activities and establish social aspects of interaction primarily in small business. The implementation of educational consultative programs and projects becomes crucial in shaping the relationship marketing and development of franchising as a form of partnership.

\section{References}

1. Berry, L. Relationship marketing [Text] / L. Berry, G. Chostack, G. Upah // In Emerging Perspectives of Service Marketing. American Marketing Association, 1983. - P. 25-38.

2. Kotler, P. Demarketing, Yes, Demarketing [Text] / P. Kotler, S. J. Levy // Brands, Consumers, Symbols, \& Research. - SAGE Publications, Inc., 1999. - P. 75-83. doi:10.4135/9781452231372.n7

3. Balabanyts, A. V. Marketynh vzaiemodii: Evoliutsiia kontseptsi i suchasni tendentsii [Text] / A. V. Balabanyts // Ekonomika i upravlenie. - 2012. - No. 6. - P. 8-13.

4. Balabanova, L. V. Marketynh vidnosyn v systemi upravlinnia pidpryiemstvom [Text]: Monograph / L. V. Balabanova, S. V. Chernysheva. - Donetsk: DonNUET, 2009. - 280 p.

5. Koval, T. A. Doslidzhennia marketynhu partnerskykh vidnosyn yak instrumentu stratehichnoho upravlinnia pidpryiemstvom [Text] / T. A. Koval, V. P. Yakhkind // Biznes Inform. - 2014. No. 4. - P. 441-448.

6. Tankov, K. M. Marketynh vzaiemovidnosyn v upravlinni lantsiuhamy postavok [Text] / K. M. Tankov // Biznes Inform. 2012. - No. 7. - P. 180-183.

7. Shtal, T. V. Elementy mehanizma vzaimodeistviia subiektov v kanalah sbyta [Text] / T. V. Shtal, Yu. B. Dobrosiuk // Biznes Inform. - 2012. - No. 10. - P. 17-22.

8. Yakhkid, V. P. Marketynh partnerskykh vidnosyn yak instrument stratehichnoho upravlinnia pidpryiemstvom [Text] / V. P. Yakhkid // Ekonomika rozvytku. - 2013. - No. 2 (66). - P. 100-104.

9. Apopii, V. V. Komertsiina diialnist [Text]: Handbook / V. V. Apopii, S. H. Babenko, Ya. A. Honcharuk et al.; ed. by V. V. Apopii. Ed. 2. - Kyiv: Znannia, 2008. - 632 p.

10. Balabanova, L. V. Upravlinnia realizatsiieiu stratehii pidpryiemstva: marketynhovyi pidkhid [Text]: Monograph / L. V. Balabanova, I. S. Folomkina. - Donetsk: DonNUET, 2009. - 402 p.

11. Verba, V. A. Stratehichni partnerstva yak model rozvytku pidpryiemstva [Text]: Monograph / V. A. Verba, O. M. Hrebeshkova // Korporatsii ta intehrovani struktury: problemy nauky ta praktyky. - Kharkiv: VD «INZhEK», 2007. - P. 244-267.

12. Lozynskyi, V. T. Formuvannia suchasnykh system dystrybutsii tovariv: problemy teorii i praktyky [Text] / V. T. Lozynskyi, I. P. Mishchuk // Visnyk Natsionalnoho universytetu «Lvivska politekhnika». - 2010. - No. 690. - P. 95-103.

13. Miziuk, B. M. Ekonomichnyi potentsial torhovelnoho pidpryiemstva: struktura, optymizatsiia, stratehichne upravlinnia [Text]: Monograph / B. M. Miziuk, O. O. Ilchuk, S. T. Duda. - Lviv: LKA, 2011. - 260 p.

14. Illiashenko, S. M. Marketynh. Menedzhment. Innovatsii [Text] Monograph / ed. by S. M. Illiashenko. - Sumy: Drukarskyi dim «Papirus», 2010. - 621 p.

15. Myshchuk, I. P. Mekhanizm aktyvizatsii prodazhu tovariv pidpryiemstvamy torhivli [Text]: Monograph / I. P. Myshchuk, N. H. Mitsenko, V. T. Lozynskyi, O. O. Khamula; ed. by I. P. Mishchuk. - Lviv: Ukrainian Academy of Printing, 2015. - 516 p.

16. Romat, Ye. V. Reklama: teoriia i praktika [Text]: Handbook Ye. V. Romat. - St. Petersburg: Piter, 2013. - 512 p.

17. Frolova, L. V. Mekhanizm lohistychnoho upravlinnia torhovelnym pidpryiemstvom [Text]: Monograph / L. V. Frolova. Donetsk: DonDUET n. a. Tugan-Baranovsky, 2005. - 322 p.

18. Heikkila, J. From supply to demand chain management: efficiency and customer satisfaction [Text] / J. Heikkila // Journal of Operation Management. - 2002. - Vol. 20, No. 6. - P. 747-767. doi:10.1016/s0272-6963(02)00038-4

19. Biekert, J. The data revolution [Text] / J. Biekert // Target Marketing. - 1992. - Vol. 15, No. 1. - P. 24-28.

20. Alderson, W. Dynamic Marketing Behavior: A Functionalist Theory of Marketing [Text] / W. Alderson. - Homewood: R. D. Irwin, 1965. - 383 p. 
21. Christopher, M. Logistics and Supply Chain Management [Text] / M. Christopher. - Ed. 5. - FT Press, 2016. - 328 p.

22. Hryhorenko, T. I. Klasyfikatsiia franchaizynhovykh merezh [Text] / T. I. Hryhorenko // Tovary i rynky. - 2011. - No. 1. - P. 36-43.

23. Dannikov, O. V. Problemy pobudovy ta funktsionuvannia franchaizynhovykh system v Ukraini [Text] / O. V. Dannikov // Marketynh v Ukraini. - 2008. - No. 5 (51). - P. 62-69.

24. Dmytryshyn, V. S. Dohovir komertsiinoi kontsesii ta dohovir franchaizynhu. Spivvidnoshennia poniat ta pravova pryroda [Text] / V. S. Dmytryshyn // Chasopys Kyivskoho universytetu prava. - 2010. - No. 3. - P. 199-203.

25. Mazurenko, V. P. Rozvytok franchaizynhovykh vidnosyn u mizhnarodnomu biznesi [Text] / V. P. Mazurenko // Naukovyi visnyk ChDIEU. - 2013. - No. 3 (19). - P. 78-84.

26. Makhnusha, S. M. Franchaizynhova forma vykorystannia brendu: pohliad z pozytsii marketynhu innovatsii [Text] / S. M. Makhnusha // Marketynh i menedzhment innovatsii. - 2010. - No. 2. P. 26-33.

27. Semenenko, I. M. Vykorystannia franchaizynhu v diialnosti promyslovykh pidpryiemstv [Text] / I. M. Semenenko // Biznes Inform. - 2012. - No. 7. - P. 102-104.

28. Cherenkov, V. I. Evoliutsiia marketingovoi teorii i transformatsiia dominiruiushchei paradigmy marketinga [Text] / V. I. Cherenkov // Vestnik Sankt-Peterburgskogo universiteta. - 2004. No. 2 (16). - P. 3-32.

29. Lisun, Y. V. Teoretyko-metodolohichni zasady formuvannia zbalansovanoho stratehichnoho potentsialu partnerskoi vzaiemodii pidpryiemstv sfery posluh [Text] / Y. V. Lisun // Naukovyi visnyk Khersonskoho derzhavnoho universytetu. - 2014. Vol. 6, No. 3. - P. 12-15.

30. Lisun, Y. V. Teoretychni aspekty formuvannia vzaiemovidnosyn u kontseptsiiakh marketynhu [Text] / Y. V. Lisun // Visnyk Odeskoho natsionalnoho universytetu im. I. I. Mechnykova. 2015. - No. 2/1 (20) - P. 70-73

31. Lisun, Y. V. Uzghodzhennia sotsialno-ekonomichnykh interesiv pidpryiemstv na osnovi refleksyvnoho pidkhodu [Text] Y. V. Lisun // Visnyk Khmelnytskoho natsionalnoho universytetu. - 2015. - Vol. 4, No. 4. - P. 27-32.

32. Zhuk, I. M. Statystychnyi shchorichnyk Ukrainy za 2015 r. [Text] / ed. by I. M. Zhuk. - State Statistics Service of Ukraine, 2016. - 575 p.

33. Franchise Group [Electronic resource]. - Available at: \www/ URL: http://franchisegroup.com.ua/

34. Lisun, Y. V. Statystychnyi analiz franchaizynhu sfery hromadskoho kharchuvannia ta torhivli v Ukraini [Text] / Y. V. Lisun // Ekonomichnyi analiz. - 2015. - No. 20. - P. 45-52.
35. Haivanovych, N. V. Merezhevi struktury malykh i serednikh pidpryiemstv [Text] / N. V. Haivanovych // Visnyk Khmelnytskoho natsionalnoho universytetu. Ekonomichni nauky. 2011. - Vol. 6, No. 4 (181). - P. 110-115.

36. Lisun, Y. V. Lohistychni systemy u zabezpechenni partnerskoi vzaiemodii pidpryiemstv [Text]: Collection of scientific articles / Y. V. Lisun // Actual problems of globalization. - 2016 . P. $195-199$.

37. Lisun, Y. V. Stages and technology in developing a strategic partnership [Text]: Collection of scientific articles / Y. V. Lisun Perspective economic and management issues. - Vienna: «East West» Association For Advanced Studies and Higher Education GmbH, 2015. - P. 449-453.

38. Lisun, Y. V. Aktyvizatsiia partnerstva na osnovi klasternoho pidkhodu yak mekhanizmu rehionalnoho rozvytku biznesu $\mathrm{v}$ Ukraini [Text]: Monograph / Y. V. Lisun // Spatial aspects of socio-economic systems development: the economy, education, and health care. - Opole: The Academy of Managemant and Fdministration in Opole, 2015. - P. 76-82.

39. Lisun, Y. V. Management contractors interests based on network model of economic development [Text]: Collection of scientific articles / Y. V. Lisun // Institutional framework for the functioning of the economy in the context of transformation. - 2015. - P. 292-297.

\section{ИССЛЕДОВАНИЕ МАРКЕТИНГА ВЗАИМОДЕЙСТВИЯ В} ФРАНЧАЙЗИНГОВОЙ ДЕЯТЕЛЬНОСТИ ТОРГОВЫХ ПРЕДПРИЯТИЙ

В работе автором уточнена сущность и составляющие понятий «маркетинг отношений», «маркетинг взаимодействия», «партнерство» в торговом предпринимательстве. Исследована сущность термина «дистрибуция» и «франчайзинг» и определено место франчайзинга в структуре организационно-правовых форм дистрибьюторских систем. Обобщены сильные и слабые стороны франчайзинговой деятельности с использованием SWOT-анализа.

Ключевые слова: предпринимательство, торговля, дистрибуция, партнеры, франчайзинг, маркетинг взаимодействия, согласования интересов, эффективность, устойчивое развитие.

Lisun Yanina, PhD, Associate Professor, Department of marketing and advertising, Kyiv National University of Trade and Economics, Ukraine, e-mail: yanalw@ukr.net, ORCID: http://orcid.org/00000002-5250-2809

\section{Kolos I. OF INDUSTRIAL ENTERPRISE ON LEAN PRINCIPLES}

Охарактеризовано матеріальний потік як складник потоку створення цінності, де відбувається зміна матеріально-речової форми виробничих запасів до готового виробу з одночасним створенням цінності для споживача. Запропоновано модель управління матеріальним потоком промислового підприємства на засадах ощадливості з використанням процесного, функціонального та системного підходів. Розкрито доречність використання сукупності методів ощадливого виробництва в реалізації окремих функцій управління матеріальним потоком промислового підприємства з орієнтацією на безперервне вдосконалення створення цінності для споживача.

Ключові слова: потік створення цінності, матеріальний потік, управління матеріальним потоком, ощадливе виробництво, промислове підприємство.

\section{Introduction}

In today's conditions, the necessary component of the production process is the availability of a sufficient number of appropriate quality of production stocks. Priority direction of increasing the efficiency of industrial enterprises is the proper provision of value to consumers of finished products. The main objective of the industrial enterprise is 